\title{
The Hybrid Finite Element Mixing Cell Method: A New Flexible Method for Modelling Mine Ground Water Problems
}

\author{
Serge Brouyère $\cdot \mathbf{P h}$. Orban $\cdot \mathrm{S}$. Wildemeersch $\cdot$ \\ J. Couturier · N. Gardin · A. Dassargues
}

Received: 3 October 2008/ Accepted: 25 March 2009

(C) Springer-Verlag 2009

\begin{abstract}
Dewatering operations often stop at mine closure. The ground water rebound can have undesirable consequences, which numerical models can help one understand and manage. However, classical modelling techniques are relatively unsuitable to these contexts. While spatially distributed and physically based models suffer difficulties due to the lack of data and the complexity of geological and hydrogeological conditions, black-box models are too simple to deal with the problems effectively. A new modelling method is proposed to simulate ground water environments in which water flows through mined (exploited) and unmined (unexploited) areas. Exploited zones are simulated using a group of mixing cells possibly interconnected by pipes. Unexploited zones are simultaneously simulated using classical finite elements. This combined approach allows explicit calculation of ground water flows around the mine and mean water levels in the exploited zones. Water exchanges between exploited zones and unexploited zones are simulated in the model using specifically defined internal boundary conditions. The method is tested on synthetic cases of increasing complexity, and first results from a real case study are presented.
\end{abstract}

S. Brouyère $(\square) \cdot$ P. Orban $\cdot S$. Wildemeersch .

J. Couturier · N. Gardin · A. Dassargues

Hydrogeology and Environmental Geology, $\mathrm{GEO}^{3}$, ArGEnCo,

Aquapôle, University of Liège, B52/3 Sart-Tilman,

4000 Liège, Belgium

e-mail: Serge.Brouyere@ulg.ac.be

S. Wildemeersch

F.R.I.A., F.R.S.-FNRS, Brussels, Belgium
Keywords Ground water flow model - Ground water rebound $\cdot$ HFEMC method $\cdot$ Mining works $\cdot$ SUFT3D

\section{Introduction}

Exploitation of ore deposits in underground mines causes significant changes in geological and hydrogeological systems. Construction of shafts, galleries and roadways is essential to extract and transport the ore. Dewatering operations are necessary as soon as the ground water level is reached. Whatever the method used (gravity drainage or pumping operations), dewatering operations modify hydrogeological conditions in the exploited zone through drawdowns of ground water levels near the exploitation and increased infiltration and seepage from the surface water network (Adams and Younger 1997). When the mine is closed, pumping is generally stopped, resulting in ground water rebound with short to long-term consequences including soil instability, flooding, acid mine drainage, and water inrushes (Younger et al. 2002). Inrushes may occur when a drainage gallery is temporarily obstructed by a rock collapse. Since water cannot drain, the water level behind the obstruction increases until it breaks under the exerted pressure, resulting in a large volume of water suddenly flowing out.

These problems can be avoided by maintaining pumping after closure. This has already been considered in several places, such as in the Durham coalfield in England (Sherwood and Younger 1994) and in the Ruhr and Saarland coal mine districts in Germany (Eckart et al. 2004). However, it is not viable in the long-term because it is expensive.

Effective tools are required to follow and predict the evolution of ground water rebound. Ground water flow 
models have proved to be particularly useful to decision makers. However, except for very large-scale applications (Sherwood and Younger 1994), classical modelling techniques are not well suited for mine water problems because classical ground water flow equations, based on Darcy's law, are not valid in exploited zones characterised by large voids constituting preferential flowpaths (Rapantova et al. 2007; Sherwood and Younger 1994, 1997; Younger et al. 2002). Even when such voids are backfilled, they still constitute preferential flowpaths with variable hydraulic conductivities that are difficult to estimate (Rapantova et al. 2007). Furthermore, lack of knowledge on hydrogeological conditions and scarcity of data concerning exploited zones and their interconnections limit the use of classical modelling techniques in mine problems. Consequently, specific modelling techniques are required.

The most recent and specific techniques developed for modelling mine water problems range from lumped box model techniques to spatially distributed, physically based techniques. Box model techniques (Sherwood and Younger 1997) represent exploited zones by boxes connected by pipes. The hydraulic gradient within each box is supposed to be flat and the exchanged fluxes between boxes are calculated from specific equations likely to take into account turbulent flow. More advanced, physically based techniques (Adams and Younger 1997; Boyaud and Therrien 2004; Younger et al. 2002) generally couple a 3D porous media for the unexploited zone with a pipe network representing the main shafts, galleries, and roadways of the exploited zone. Recently, Eckart et al. (2004) have also proposed a combined but still decoupled approach where the coalfield is conceptualised using interconnected boxes while the overlying aquifers are modelled using classical finite elements. The simplest techniques, such as box models, are easy to use and most often accurate enough to model water levels in the exploited zones. However, they do not allow explicit consideration of the complex interactions between the exploited zones and their surrounding environment. The most complicated approaches, such as spatially distributed and physically based models, require accurate data and very detailed information on the underground geometry, together with advanced parameterisation. These parameters are most often not available, except at a very local scale.

The hybrid finite element mixing cell (HFEMC) method presented here is a compromise between simple and complex techniques. It fully couples groups of mixing cells used to model exploited zones with classical finite elements used to model unexploited zones. Ground water flows between the exploited and unexploited zones are considered using internal boundary conditions defined at the interfaces between the boxes and the finite element mesh. Furthermore, by-pass flows through connections between exploited zones, such as old shafts and galleries, can be taken into account using first order transfer equations between the connected boxes. It is also possible to switch these connections on and off depending on the simulated water levels to allow simulation of specific phenomena linked to ground water rebound (e.g. water inrushes). The HFEMC method was implemented in the SUFT3D (Saturated and Unsaturated Flow and Transport in 3D) finite element code (Brouyère 2001; Brouyère et al. 2004; Carabin and Dassargues 1999).

The objective here is to present the concepts and equations of the HFEMC method, to show validation on test cases of increasing complexity, and first results obtained at a real application case study corresponding to an abandoned underground coal mine in the region of Liège, Belgium.

\section{Concepts and Equations of the HFEMC Method}

The flexibility of the HFEMC method allows the ground water flow problem to be solved by simultaneously using different types of ground water flow equations. The fundamental principle of the method consists of dividing the modelled zone into several sub-domains and selecting one type of ground water flow equation for each of them. A general schema of the HFEMC method is given in Fig. 1.

Ground water flow equations that are considered in the SUFT3D code are the simple linear reservoir (Eq. 1a), the distributed linear reservoir (Eq. 1b) and the classical ground water flow equation in equivalent porous media (Eq. 1c).

$Q_{\mathrm{LR}}=S_{\mathrm{LR}} A_{\mathrm{LR}, \text { upper }} \frac{\partial H_{\mathrm{LR}}}{\partial t}=-\alpha_{\mathrm{LR}} A_{\mathrm{LR}, \text { lat }}\left(H_{\mathrm{LR}}-H_{\mathrm{ref}}\right)+Q$

$\begin{aligned} Q_{\mathrm{LR}, i} & =S_{\mathrm{LR}, i} A_{\mathrm{LR}, \text { upper }, i} \frac{\partial H_{\mathrm{LR}, i}}{\partial t} \\ & =\sum_{j=1}^{n} \alpha_{i j} A_{\mathrm{LR}, \text { lat }, i}\left(H_{\mathrm{LR}, j}-H_{\mathrm{LR}, i}\right)+Q_{i}\end{aligned}$

$F \frac{\partial h}{\partial t}=\underline{\nabla}(\underline{\underline{K}} \underline{\nabla}(h+z))+q$

where $Q_{\mathrm{LR}}$ flow rate entering or leaving the linear reservoir $\left(\mathrm{L}^{3} \mathrm{~T}^{-1}\right), S_{\mathrm{LR}}$ specific storage of the linear reservoir (-), $A_{\mathrm{LR} \text {,upper }}$ area of the upper face of the linear reservoir $\left(\mathrm{L}^{2}\right)$, $H_{\mathrm{LR}}$ mean hydraulic head in the linear reservoir (L), $\alpha_{\mathrm{LR}}$ exchange coefficient of the linear reservoir $\left(\mathrm{T}^{-1}\right), A_{\mathrm{LR}, \text { lat }}$ area of the draining lateral face of the linear reservoir $\left(\mathrm{L}^{2}\right)$, $H_{\text {ref }}$ drainage level of the linear reservoir (L), $Q$ source/sink term $\left(\mathrm{L}^{3} \mathrm{~T}^{-1}\right), F$ specific storage coefficient of the porous medium $\left(\mathrm{L}^{-1}\right), h$ pressure potential $(\mathrm{L}), \underline{\underline{K}}$ hydraulic 

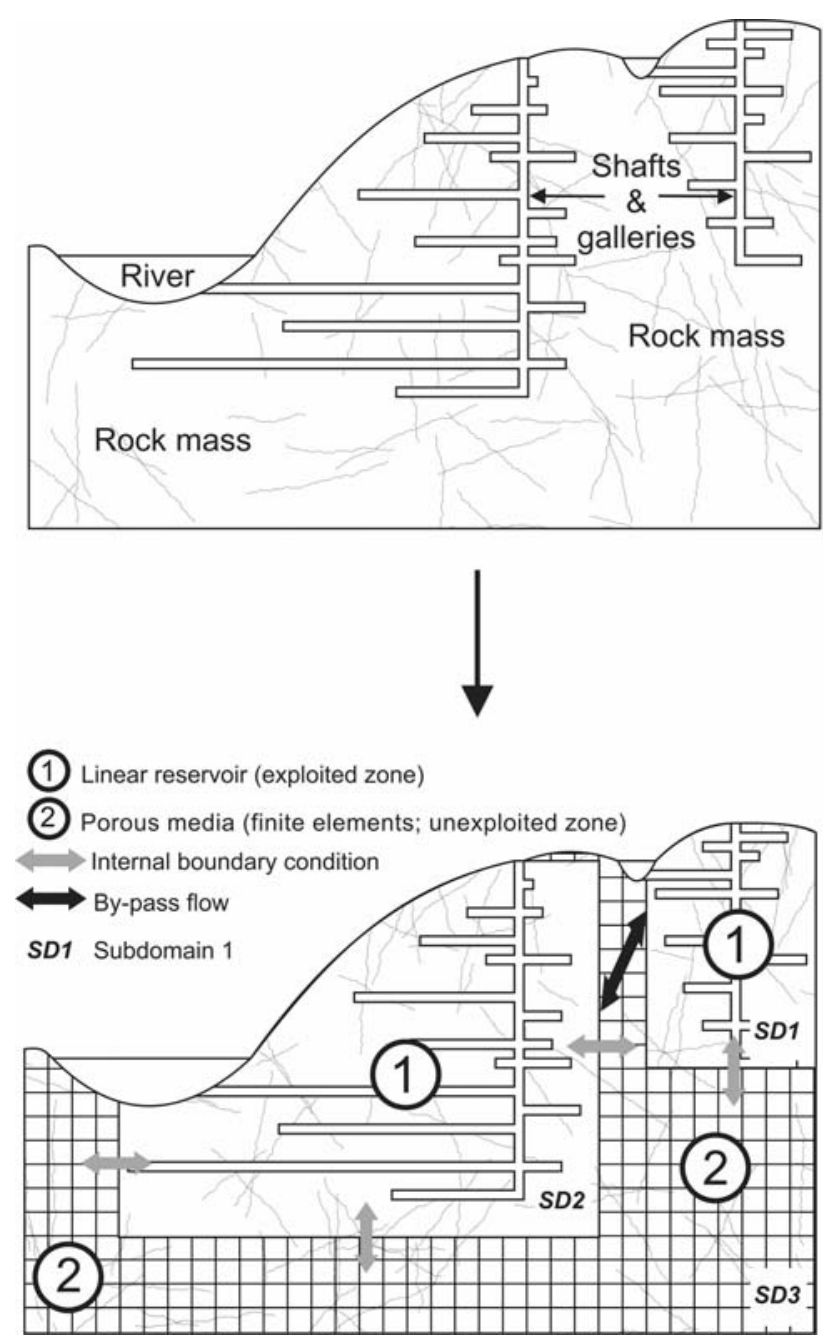

Fig. 1 General schema of the HFEMC method showing the subdivision of the modelled zone into sub-domains and the choice of one ground water flow equation for each of them

conductivity tensor $\left(\mathrm{LT}^{-1}\right), z$ gravity potential $(\mathrm{L})$, and $q$ source/sink term by unit volume $\left(\mathrm{T}^{-1}\right)$.

The choice of one equation rather than another is motivated by the level of knowledge of the hydrogeological conditions and by the validity of the equation in each sub-domain. As previously mentioned, the classical flow equation for porous media is not well-suited to the mining context. Exploited zones are usually less well characterised hydrogeologically than surrounding unexploited zones. Our approach is to subdivide the domain of interest into exploited zones modelled using linear reservoirs and unexploited zones modelled using classical ground water flow equations as expressed for equivalent porous media (solved by a finite element technique). Exploited zones are discretised by a group of a mixing cells characterised by a calculated mean water level, which is equivalent to a box model technique. Unexploited zones are discretised by finite elements providing computed spatially distributed hydraulic heads obtained through the finite element solution of the ground water flow equation in a porous medium. For transient problems, a classical finite difference discretisation in time is used.

Internal boundary conditions are defined at the interfaces between mixing cells and finite elements. They deal with ground water fluxes between sub-domains and computation of separate ground water balances for each subdomain. Three types of internal boundary conditions are available. Dirichlet (first-type) dynamic boundary conditions (Eq. 2a) are used where equality of hydraulic heads along the internal boundary is assumed. The hydraulic head is variable with time and an unknown of the problem. Neumann (second-type) impervious (or zero flux) boundary conditions (Eq. 2b) are defined at internal boundaries where it is assumed that there is no exchange of water between the sub-domains. Cauchy (third-type) dynamic boundary conditions (Eq. 2c) can be used to couple subdomains based on the computation of a flux that depends on the difference between hydraulic heads on each side of the internal boundary. The Dirichlet dynamic boundary condition preserves the continuity of the hydraulic head field, the Neumann impervious boundary condition is a zero-flux boundary condition, and the Cauchy dynamic boundary condition ensures that the volume of water that leaves one sub-domain enters another sub-domain. Mass conservation between the sub-domains is thus ensured when using the HFEMC method.

$h_{\mathrm{SD}, i}(x, y, z, t)=h_{\mathrm{SD}, j}(x, y, z, t)$

$\frac{\partial h(x, y, z, t)}{\partial n}=0$

$Q_{\mathrm{SD}, i-\mathrm{SD}, j}=\alpha_{\mathrm{FBC}} A\left\lfloor h_{\mathrm{SD}, j}(x, y, z, t)-h_{\mathrm{SD}, i}(x, y, z, t)\right\rfloor$

where $h_{\mathrm{SD}, i}$ the hydraulic head in sub-domain $i(\mathrm{~L}), h_{\mathrm{SD}, j}$ the hydraulic head in sub-domain $j$ (L), $Q_{\mathrm{SD}, i-\mathrm{SD}, j}$ exchanged flow between sub-domains $i$ and $j$ through the third-type of internal boundary condition $\left(\mathrm{L}^{3} \mathrm{~T}^{-1}\right), \alpha_{\mathrm{FBC}}$ exchange coefficient for the third type of internal boundary condition $\left(\mathrm{T}^{-1}\right)$, and $A$ the exchange area for the third type of internal boundary condition $\left(\mathrm{L}^{2}\right)$.

The exchange coefficient $\alpha_{\mathrm{FBC}}$ (units $\mathrm{T}^{-1}$ ) used in the Cauchy dynamic boundary conditions (Eq. 2c) depends on the hydraulic conductivity on both sides of the interface between the interacting sub-domains. It is adjusted during the calibration process since it is difficult to estimate from field data.

By-pass flows through connections between boxes corresponding to exploited zones interconnected by old shafts or galleries are modelled using a first order transfer equation (Eq. 3). 


$$
Q_{\mathrm{SD}, i-\mathrm{SD}, j}=\alpha_{\mathrm{BF}}\left\lfloor h_{\mathrm{SD}, j}(x, y, z, t)-h_{\mathrm{SD}, i}(x, y, z, t)\right\rfloor
$$

In this case, the exchange coefficient $\alpha_{\mathrm{BF}}$ (units $\mathrm{L}^{2} \mathrm{~T}^{-1}$ ) represents the strength of head losses along preferential flow paths.

\section{Verification and Illustration of the HFEMC Method}

To assess the implementation of the HFEMC method and its application to mine water problems, a series of synthetic examples were developed and modelled using the SUFT3D code. The first two test cases were used to verify the numerical implementation of the HFEMC method through a comparison with available analytical solutions on simplified examples. The third and fourth examples assessed the flexibility and potential of the proposed method for modelling mine water problems.

First Verification Test Case: Sub-Domains and Internal Boundary Conditions

The first test case was performed to illustrate the subdivision into sub-domains and the use of internal boundary conditions. A schematic representation of the modelled example is given in Fig. 2.

The mesh was divided into two sub-domains. The first one (SD1), representing the unexploited rock mass, was modelled using classical finite elements. The second one (SD2), representing the exploited zone, was modelled as a linear reservoir. The third type of dynamic internal boundary conditions was prescribed at the interface

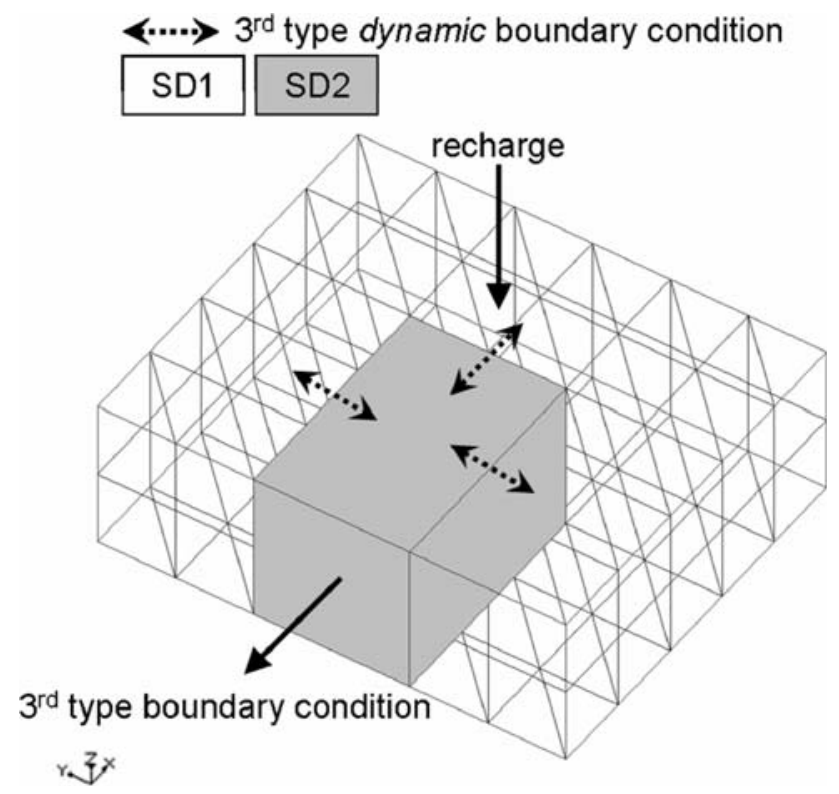

Fig. 2 First verification test case: schema between SD1 and SD2 and at the external lateral face of SD2. The lateral external faces of SD1 are considered as impervious and a constant recharge was prescribed on the upper faces of the entire mesh. The model was run in steady-state conditions with the set of parameters given in Table 1.

Based on the selection of boundary conditions, water enters into the system through recharge and it is drained out through the boundary condition applied to SD2. The rock mass is drained through seepage from SD1 to SD2 across their common interface. Using Eq. 1a and the set of parameters given in Table 1, the mean water level in SD2 can be calculated analytically as follows:

$$
\begin{aligned}
H_{\mathrm{SD} 2} & =H_{\text {ref }}+\frac{R A_{\text {recharge }}}{\alpha_{\mathrm{SD} 2-\mathrm{ext}} A_{\mathrm{SD} 2-\mathrm{ext}}}=5+\frac{6 \times 10^{-9} \times 75,000}{10^{-5} \times 10,000} \\
& =5.0045
\end{aligned}
$$

where $H_{\mathrm{SD} 2}$ the mean water level in SD2 (L).

Figure 3 presents the simulated hydraulic heads, using the SUFT3D and the HFEMC method. The analytical and numerical solutions for the mean water level in the mined area (SD2) are identical $(5.0045 \mathrm{~m})$. Figure 3 also shows clearly that the rock mass around (SD1) is drained laterally to the mined system (SD2).

Second Verification Test Case: Modelling Transient Ground Water Flows in a Mined System

The second test case was performed to illustrate the use of the linear reservoir equation in transient ground water flow conditions. A parallelepiped mesh of $1,500,000 \mathrm{~m}^{3}$ was modelled as a linear reservoir with a specific storage of $25 \%\left(S_{\mathrm{LR}}\right)$. The third type of external boundary condition was prescribed at a lateral face of the linear reservoir covering $10,000 \mathrm{~m}^{2}$ ( $\left.A_{\mathrm{LR}, \mathrm{lat}}\right)$, with an exchange coefficient

Table 1 First test case: parameters

\begin{tabular}{ll}
\hline Parameter & Value \\
\hline$K_{\mathrm{SD} 1}(\mathrm{~m} / \mathrm{s})$ & $1 \times 10^{-5}$ \\
$R(\mathrm{~m} / \mathrm{s})$ & $6 \times 10^{-9}$ \\
$H_{\text {ref }}(\mathrm{m})$ & 5 \\
$\alpha_{\mathrm{SD} 2 \text {-ext }}\left(\mathrm{s}^{-1}\right)$ & $1 \times 10^{-5}$ \\
$\alpha_{\mathrm{SD} 1-\mathrm{SD} 2}\left(\mathrm{~s}^{-1}\right)$ & $1 \times 10^{-1}$ \\
$A_{\text {recharge }}\left(\mathrm{m}^{2}\right)$ & 75,000 \\
$A_{\mathrm{SD} 2 \text {-ext }}\left(\mathrm{m}^{2}\right)$ & 10,000 \\
\hline
\end{tabular}

$K_{\mathrm{SD} 1}$ hydraulic conductivity of the unexploited zone $\mathrm{SD} 1\left(\mathrm{LT}^{-1}\right), R$ recharge rate $\left(\mathrm{LT}^{-1}\right), H_{\text {ref }}$ drainage level of the exploited zone SD2 (L), $\alpha_{\text {SD2-ext }}$ exchange coefficient for the third type external boundary condition of SD2 $\left(\mathrm{T}^{-1}\right), \alpha_{\mathrm{SD} 1-\mathrm{SD} 2}$ exchange coefficient for the third type internal boundary condition between SD1 and SD2 $\left(\mathrm{T}^{-1}\right)$, $A_{\text {recharge }}$ recharge area $\left(\mathrm{L}^{2}\right), A_{\mathrm{SD} 2 \text {-ext }}$ exchange area for the third type external boundary condition of SD2 $\left(\mathrm{L}^{2}\right)$ 


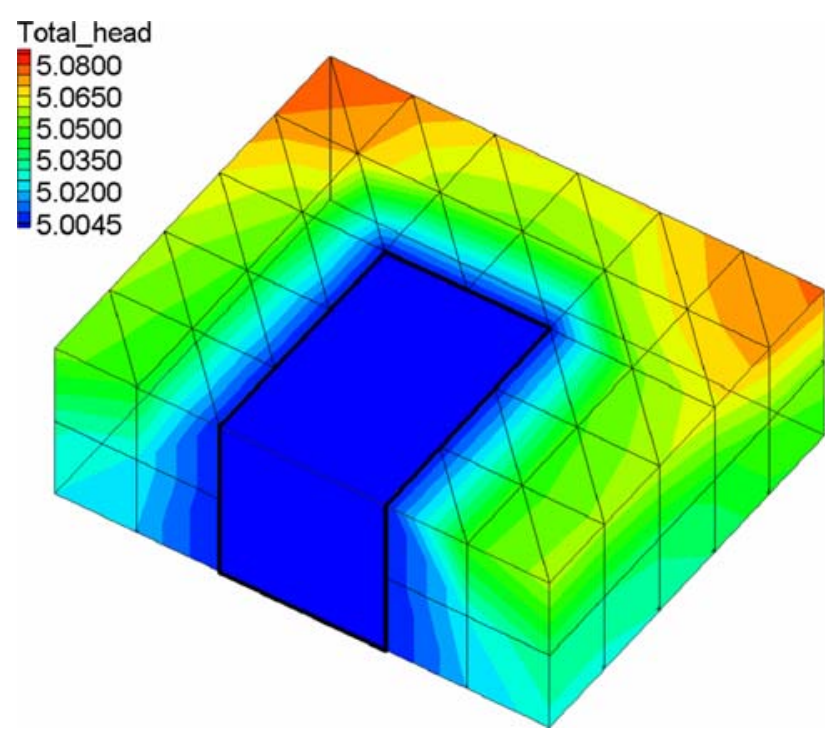

Fig. 3 First verification test case: simulated hydraulic heads (in metres)

of $10^{-6} \mathrm{~s}^{-1}\left(\alpha_{\mathrm{LR}}\right)$ and a drainage level of $5 \mathrm{~m}\left(H_{\mathrm{ref}}\right)$. A variable recharge was prescribed on its upper face covering $15,000 \mathrm{~m}^{2}\left(A_{\mathrm{LR} \text {,upper }}\right)$. No recharge was applied during the first 4 days and a constant recharge $10^{-5} \mathrm{~m} / \mathrm{s}$ was applied during the following days. The initial water level in the reservoir was set at $25 \mathrm{~m}\left(H_{0}\right)$, i.e. $20 \mathrm{~m}$ above the drainage level at the third-type external boundary condition. The numerical simulation was performed using 960 constant time steps of 3,600 s. The analytical (Eq. 5) and numerical solutions are compared in Fig. 4.

$$
\begin{aligned}
H_{\mathrm{LR}}= & \left(H_{0}-\frac{\alpha_{\mathrm{LR}} A_{\mathrm{LR}, \text { lat }} H_{\mathrm{ref}}+Q}{\alpha_{\mathrm{LR}}}\right) e^{\frac{\alpha_{\mathrm{LR}}}{\overline{\mathrm{L}}_{\mathrm{LR}, \text { upper }}} t} \\
& +\frac{\alpha_{\mathrm{LR}} A_{\mathrm{LR}, \mathrm{lat}} H_{\mathrm{ref}}+Q}{\alpha_{\mathrm{LR}}}
\end{aligned}
$$

During the first 4 days, the reservoir was progressively drained through the external boundary condition. After 4 days, once a recharge was prescribed, the linear reservoir was progressively refilled, until a steady-state regime was reached.

\section{Third Illustration Test Case: By-Pass Flows}

The third test case was performed to illustrate the capacity of the HFEMC method to model by-pass flows between different mined zones. A schematic representation of the modelled example is given in Fig. 5.

The mesh was divided into three sub-domains. The first sub-domain (SD1) represents the unexploited rock mass, modelled using classical finite elements. The two others (SD2 and SD3) correspond to exploited zones, modelled as linear reservoirs. These two mined zones were assumed to be connected by an old gallery constituting a preferential flowpath and were modelled using a first-order transfer equation. Third-type dynamic boundary conditions (internal boundary conditions) were prescribed at the interfaces between the rock mass (SD1) and the two exploited zones (SD2 and SD3). A third type external boundary condition was also prescribed at the external lateral faces of SD3 and at the south external lateral faces of SD1, to account for natural drainage of the mined system to surface water. Other external boundaries of SD1 were considered as impervious.
Fig. 4 Second verification test case: comparison between analytical and numerical solution of the simple linear reservoir equation in transient regime

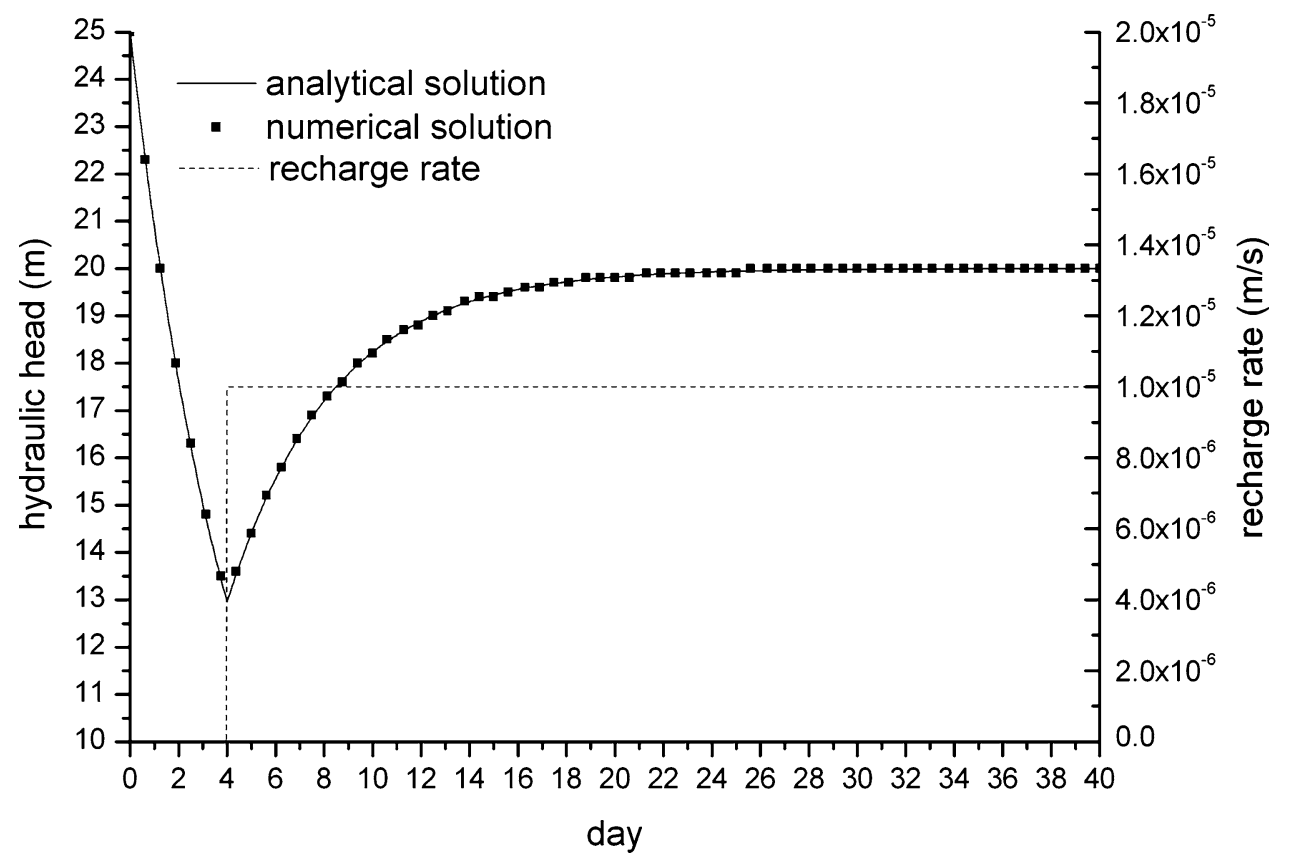



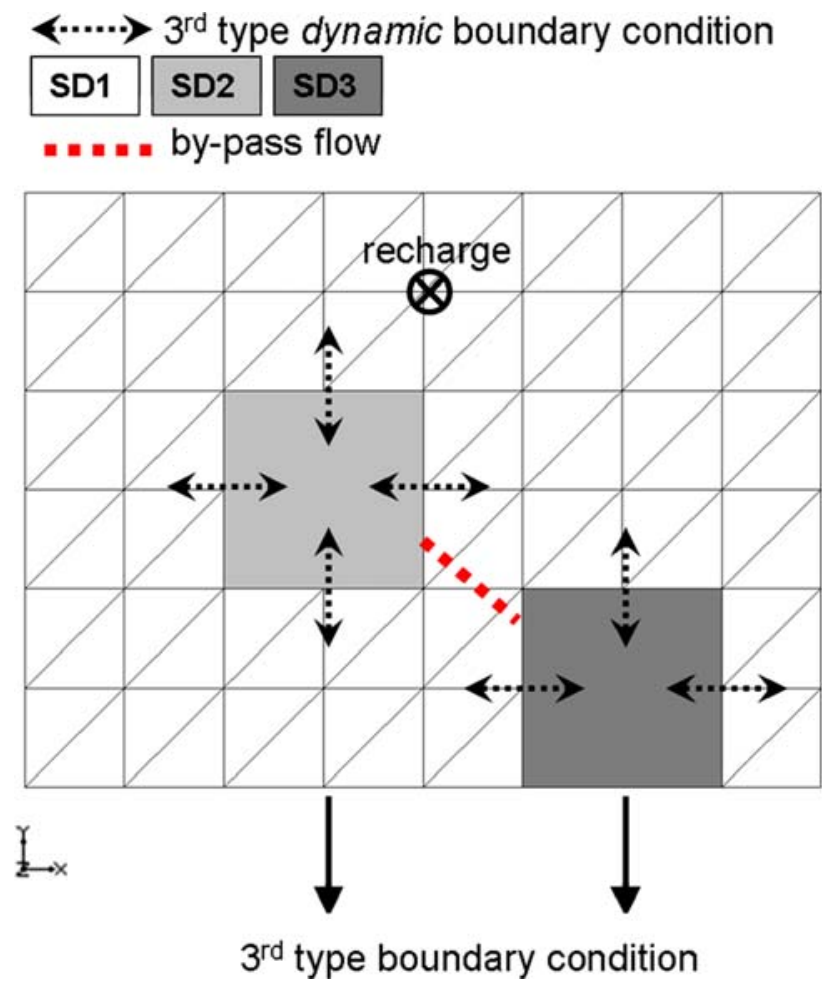

Fig. 5 Third illustration test case: schema

A constant recharge was prescribed on the upper faces of the entire mesh. The model was run in steady-state conditions with the set of parameters given in Table 2.

Figure 6a shows simulated hydraulic heads for the entire mesh without by-pass flow between the two exploited zones (SD2 and SD3), i.e. assuming that the first order transfer coefficient between these two zones is equal to zero. Figure $6 \mathrm{~b}$ shows the same simulation but considering by-pass flow between SD2 and SD3. The simulated mean water level in SD2 is higher in the first case than in the second case. Indeed, in the absence of by-pass flow between SD2 and $\mathrm{SD} 3, \mathrm{SD} 2$ is only drained through the low-permeability rock mass around. At the same time, resulting ground water levels in SD1 are also higher because of the less efficient drainage capacity of the mined system. With by-pass flow between $\mathrm{SD} 2$ and SD3, SD2 is still drained through the rock mass around but also through the direct connection with SD3. The outflow of ground water is thus facilitated and ground water levels are depleted throughout the mined system. The simulated mean water level in SD3 is the same in both cases as it is governed by the exchange coefficient of the third-type external boundary condition.

\section{Fourth Illustration Test Case: Modelling Water Inrush} Phenomenon

The fourth test case was performed to illustrate the capacity of the HFEMC method to model water inrushes. The same
Table 2 Third test case: parameters

\begin{tabular}{ll}
\hline Parameter & Value \\
\hline$K_{\mathrm{SD} 1}(\mathrm{~m} / \mathrm{s})$ & $1 \times 10^{-4}$ \\
$R(\mathrm{~m} / \mathrm{s})$ & $6.90 \times 10^{-9}$ \\
$H_{\text {ref }}(\mathrm{m})$ & 26 \\
$\alpha_{\mathrm{SD} 1-\mathrm{ext}}\left(\mathrm{s}^{-1}\right)$ & $1 \times 10^{-6}$ \\
$\alpha_{\mathrm{SD} 3-\mathrm{ext}}\left(\mathrm{s}^{-1}\right)$ & $1 \times 10^{-3}$ \\
$\alpha_{\mathrm{SD} 1-\mathrm{SD} 2}\left(\mathrm{~s}^{-1}\right)$ & $1 \times 10^{-6}$ \\
$\alpha_{\mathrm{SD} 1-\mathrm{SD} 3}\left(\mathrm{~s}^{-1}\right)$ & $1 \times 10^{-4}$ \\
$\mathrm{~A}_{\text {recharge }}\left(\mathrm{m}^{2}\right)$ & 120,000 \\
$\mathrm{~A}_{\mathrm{SD} 1-\mathrm{ext}}\left(\mathrm{m}^{2}\right)$ & 15,000 \\
$\mathrm{~A}_{\mathrm{SD} 3-\mathrm{ext}}\left(\mathrm{m}^{2}\right)$ & 5,000 \\
$\alpha_{\mathrm{SD} 2-\mathrm{SD} 3}\left(\mathrm{~m}^{2} / \mathrm{s}\right)$ & $1 \times 10^{-2}$ \\
\hline$K_{\mathrm{SD1}}$ &
\end{tabular}

$K_{\mathrm{SD} 1}$ hydraulic conductivity of the unexploited zone SD1 $\left(\mathrm{LT}^{-1}\right), R$ recharge rate $\left(\mathrm{LT}^{-1}\right), H_{\text {ref }}$ drainage level of the unexploited zone SD1 and the exploited zone SD3 (L), $\alpha_{\text {SD1-ext }}$ exchange coefficient for the third type external boundary condition of SD1 $\left(\mathrm{T}^{-1}\right), \alpha_{\mathrm{SD} 3 \text {-ext }}$ exchange coefficient for the third type external boundary condition of SD3 $\left(\mathrm{T}^{-1}\right), \alpha_{\mathrm{SD} 1-\mathrm{SD} 2}$ exchange coefficient for the third type internal boundary condition between SD1 and SD2 $\left(\mathrm{T}^{-1}\right), \alpha_{\mathrm{SD} 1-\mathrm{SD} 3}$ exchange coefficient for the third type internal boundary condition between SD1 and SD3 $\left(\mathrm{T}^{-1}\right), A_{\text {recharge }}$ recharge area $\left(\mathrm{L}^{2}\right), A_{\mathrm{SD} 1 \text {-ext }}$ exchange area for the third type external boundary condition of SD1 $\left(\mathrm{L}^{2}\right), A_{\mathrm{SD} 3}$ ext exchange area for the third type external boundary condition of SD3 $\left(\mathrm{L}^{2}\right), \alpha_{\mathrm{SD} 2-\mathrm{SD} 3}$ first order transfer coefficient for by-pass flow between SD2 and SD3 $\left(\mathrm{L}^{2} \mathrm{~T}^{-1}\right)$

schema as the third test case was used (Fig. 5). The model has three phases. Phase I simulates a period when the bypass flow between the two exploited zones SD2 and SD3 works normally. The first order transfer coefficient was thus set higher than zero. Then, a rock collapse occurs, obstructing the connection. This second phase (phase II) is characterised by a first order transfer coefficient equal to zero, to simulate the absence of flux exchanges between $\mathrm{SD} 2$ and SD3. As a consequence, the water level behind the obstruction begins to increase until the exerted pressure ( $\left.h_{\text {threshold }}\right)$ ends up breaking the obstruction, inducing a water inrush. Phase III simulates the period following the obstruction break when the by-pass flow between SD2 and SD3 starts again. The first order transfer coefficient is thus reset higher than zero. The set of parameters used for the entire simulation is given in Table 3 .

First, the simulation was performed by disconnecting the unexploited zone SD1 of the mesh, using the box model technique with two interconnected boxes, SD2 and SD3. Then, the simulation was performed using the HFEMC method. Figure 7 allows you to compare the hydraulic heads and exchanged flow rates obtained, respectively, with the box model technique (Fig. 7a) and the HFEMC method (Fig. 7b).

With both methods, the general shape of the curves is identical. The first phase is characterised by a decrease in 

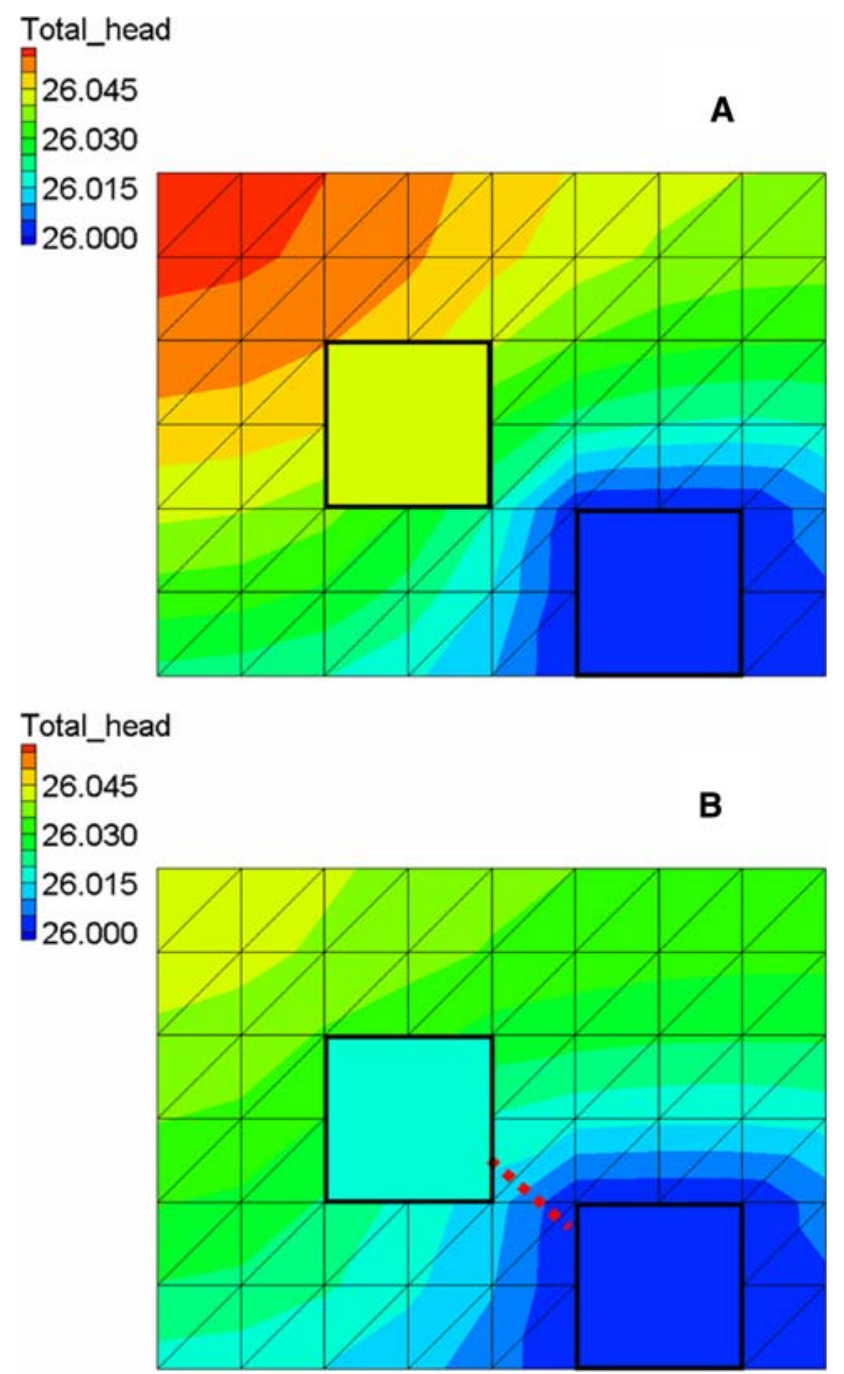

Fig. 6 Third illustration test case: hydraulic heads (in metres) simulated a without by-pass flow between SD2 and SD3 and b with by-pass flow between SD2 and SD3

hydraulic heads until steady state is reached. As the hydraulic head in SD3 is governed by the third type of external boundary condition with a relatively high exchange coefficient, the decrease in SD3 is particularly quick. After the rock collapse, the connection between SD2 and SD3 is obstructed. There is no more by-pass flow and hydraulic head in SD2 increased until the obstruction breaks. The third phase was characterised by a decrease in hydraulic head in SD2 until a new steady state was reached, which is different from the first one because the first-order transfer coefficient was set slightly lower after the obstruction broke.

Comparing the hydraulic heads and exchange fluxes in detail, some differences appear between the box model technique and the HFEMC method. The hydraulic heads values reached at the end of the first and the third phases
Table 3 Fourth test case: parameters

\begin{tabular}{ll}
\hline Parameter & Value \\
\hline$K_{\mathrm{SD} 1}(\mathrm{~m} / \mathrm{s})$ & $1 \times 10^{-4}$ \\
$R(\mathrm{~m} / \mathrm{s})$ & $1 \times 10^{-6}$ \\
$H_{\text {ref }}(\mathrm{m})$ & 26 \\
$\alpha_{\mathrm{SD} 1-\mathrm{ext}}\left(\mathrm{s}^{-1}\right)$ & $1 \times 10^{-6}$ \\
$\alpha_{\mathrm{SD} 3 \text {-ext }}\left(\mathrm{s}^{-1}\right)$ & $1 \times 10^{-3}$ \\
$\alpha_{\mathrm{SD} 1-\mathrm{SD} 2}\left(\mathrm{~s}^{-1}\right)$ & $1 \times 10^{-6}$ \\
$\alpha_{\mathrm{SD} 1-\mathrm{SD} 3}\left(\mathrm{~s}^{-1}\right)$ & $1 \times 10^{-4}$ \\
$A_{\text {recharge }}\left(\mathrm{m}^{2}\right)$ & 120,000 \\
$A_{\mathrm{SD} 1-\mathrm{ext}}\left(\mathrm{m}^{2}\right)$ & 15,000 \\
$A_{\mathrm{SD} 3 \text {-ext }}\left(\mathrm{m}^{2}\right)$ & 5,000 \\
$\alpha_{\mathrm{SD} 2-\mathrm{SD} 3}\left(\mathrm{~m}^{2} / \mathrm{s}\right)$ & $1 \times 10^{-2}$ (phase I) \\
& $0($ phase II) \\
$h_{\text {threshold }}(\mathrm{m})$ & $7 \times 10^{-3}$ (phase III) \\
\hline$K_{\mathrm{SD} 1}$ hydraulc & 31.50 \\
\hline
\end{tabular}

$K_{\mathrm{SD} 1}$ hydraulic conductivity of the unexploited zone $\mathrm{SD} 1\left(\mathrm{LT}^{-1}\right), R$ recharge rate $\left(\mathrm{LT}^{-1}\right), H_{\text {ref }}$ drainage level of the unexploited zone SD1 and the exploited zone SD3 (L), $\alpha_{\mathrm{SD} 1-e x t}$ exchange coefficient for the third type external boundary condition of SD1 $\left(\mathrm{T}^{-1}\right), \alpha_{\mathrm{SD} 3 \text {-ext }}$ exchange coefficient for the third type external boundary condition of SD3 $\left(\mathrm{T}^{-1}\right), \alpha_{\mathrm{SD} 1-\mathrm{SD} 2}$ exchange coefficient for the third type internal boundary condition between SD1 and SD2 $\left(\mathrm{T}^{-1}\right), \alpha_{\mathrm{SD} 1-\mathrm{SD} 3}$ exchange coefficient for the third type internal boundary condition between $\mathrm{SD} 1$ and SD3 $\left(\mathrm{T}^{-1}\right), A_{\text {recharge }}$ recharge area $\left(\mathrm{L}^{2}\right), A_{\mathrm{SD} 1 \text {-ext }}$ exchange area for the third type external boundary condition of SD1 $\left(\mathrm{L}^{2}\right)$, $A_{\text {SD3-ext }}$ exchange area for the third type external boundary condition of SD3 $\left(\mathrm{L}^{2}\right), \alpha_{\mathrm{SD} 2-\mathrm{SD} 3}$ first order transfer coefficient for by-pass flow between SD2 and SD3 $\left(\mathrm{L}^{2} \mathrm{~T}^{-1}\right), h_{\text {threshold }}$ water level threshold above which the obstruction breaks (L)

are less with the box model technique than with the HFEMC method. As the HFMEC method accounts for interactions between the unexploited zone SD1 and the unexploited zones SD2 and SD3, it is logical since, via third type dynamic internal boundary conditions, SD2 and SD3 receive water coming from SD1 in addition to water coming directly from the recharge. The time necessary to reach the water level threshold above which the obstruction breaks is shorter with the HFEMC method (about 18 days) than with the box model technique (about 22.5 days) for the same reason. It is also interesting to point out the increase of hydraulic head in SD2 during the second phase. With the box model technique, this increase is linear because water in SD2 cannot be evacuated at all. Conversely, with the third type of dynamic boundary conditions of the HFEMC method, a volume of water can still be evacuated through adjacent porous media and the hydraulic head in SD2 tends to stabilize, which is more realistic. The values of exchanged fluxes reached at the end of the first and the third phases are less with the box model technique than with the HFEMC method because of the difference in hydraulic heads previously mentioned. On the other hand, 
A

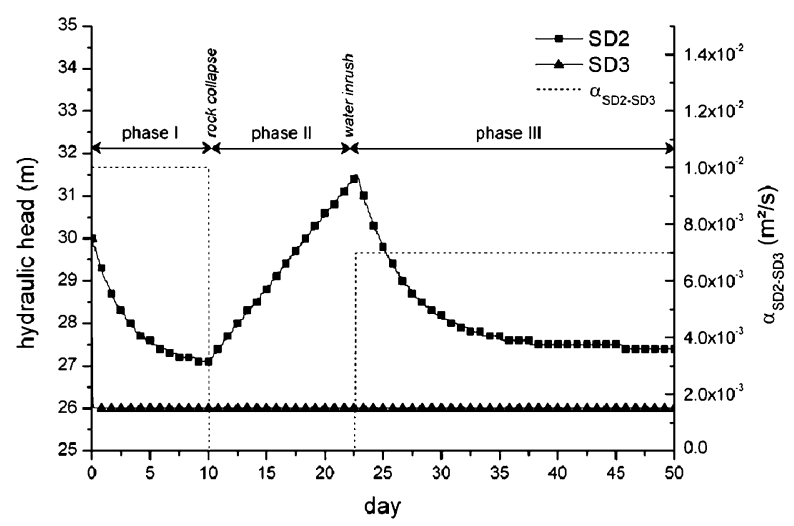

B

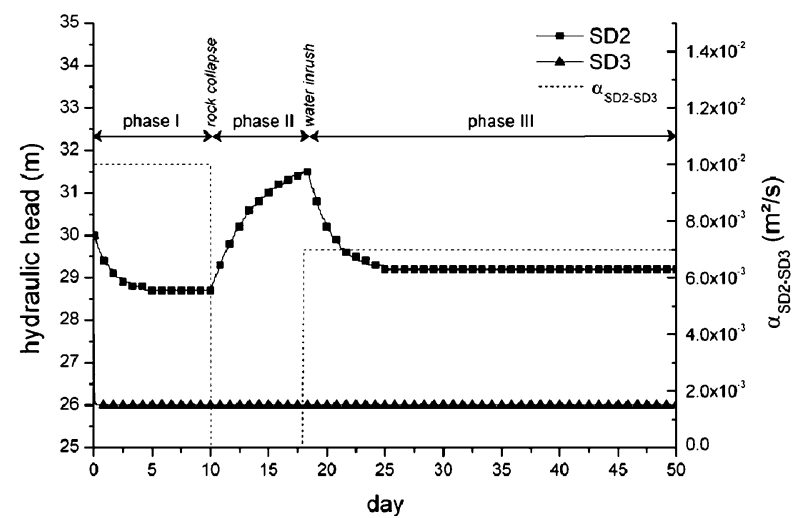

A

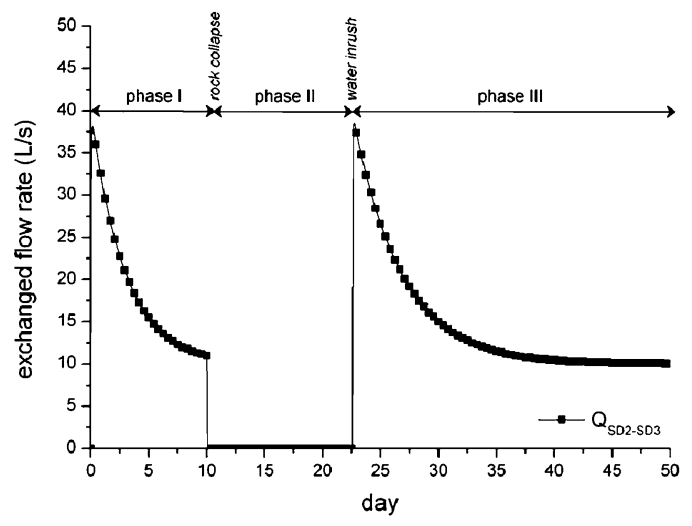

B

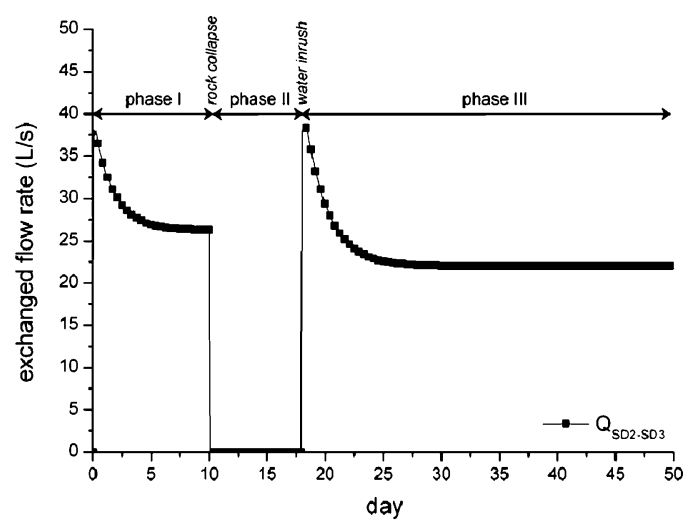

Fig. 7 Fourth illustration test case: comparison of hydraulic heads and exchanged flow rates as obtained using the box model technique (a) and the HFEMC method (b)

flow rates corresponding to the water inrush are the same because the hydraulic head threshold above which the obstruction breaks is the same $(34 \mathrm{~m})$.

\section{Application of the HFEMC Method to the Cheratte Coalfield}

The site of Cheratte is located in eastern Belgium, near the city of Liège (Fig. 8). This underground coal mine was abandoned in 1982. It was part of the Liège coalfield, the most eastern part of the major coal deposits of the Haine, Sambre, and Meuse rivers valleys. The studied area covers about $27 \mathrm{~km}^{2}$.

\section{Geology and Hydrogeology}

The geology of the studied area has been described by Barchy and Marion (2000) (Fig. 9). The oldest exposed rocks are Upper Carboniferous (Namurian and Westphalian) in age. These rocks are usually grouped together in the Houiller Group (HOU). The HOU consists of a succession of shales and silts with intercalations of sandstones, quartzites, and coal seams. These layers were folded and faulted during the Variscan orogeny. Tabular Cretaceous formations were deposited above these Upper Carboniferous rocks. The Cretaceous formations are the Vaals formation (VAA), comprising clays and sands, and the Gulpen formation (GUL), which is mainly made of chalk. At the end of the Pliocene, terraces (ALA) containing clays, silts, and sands were emplaced. The bottom of the Meuse river valley is occupied by modern alluvial deposits (AMO), mainly pebbles, sands, and clays.

The hydrogeology of the studied zone has been recently compiled and mapped by Ruthy and Dassargues (2008). The main aquifers are located in the alluvial deposits of the Meuse River and in the chalk of the GUL. Local aquifers are also found in fissured rocks of the HOU. The chalky aquifer and local fissured aquifers of the HOU are separated by low-permeability clays of the VAA. A minor aquifer is also located in the terraces of the Meuse River. 
Fig. 8 Location of the case study zone

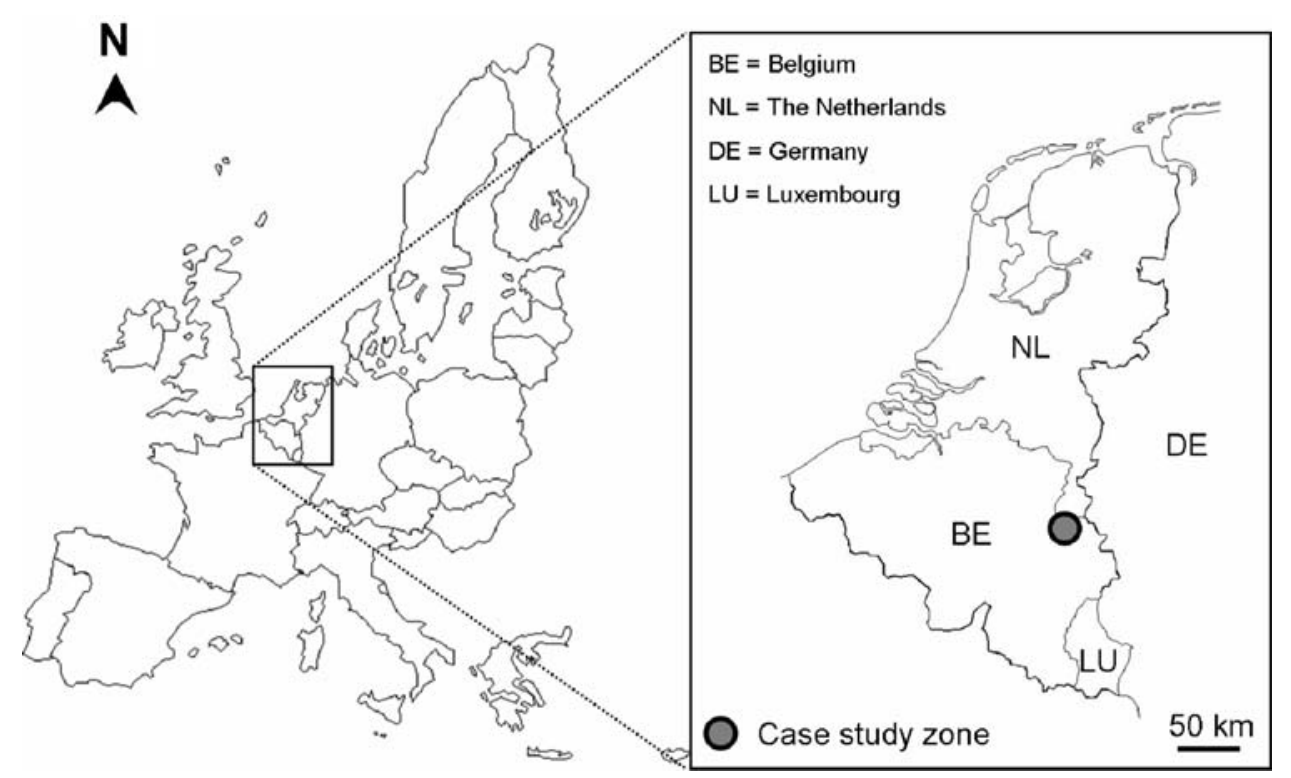

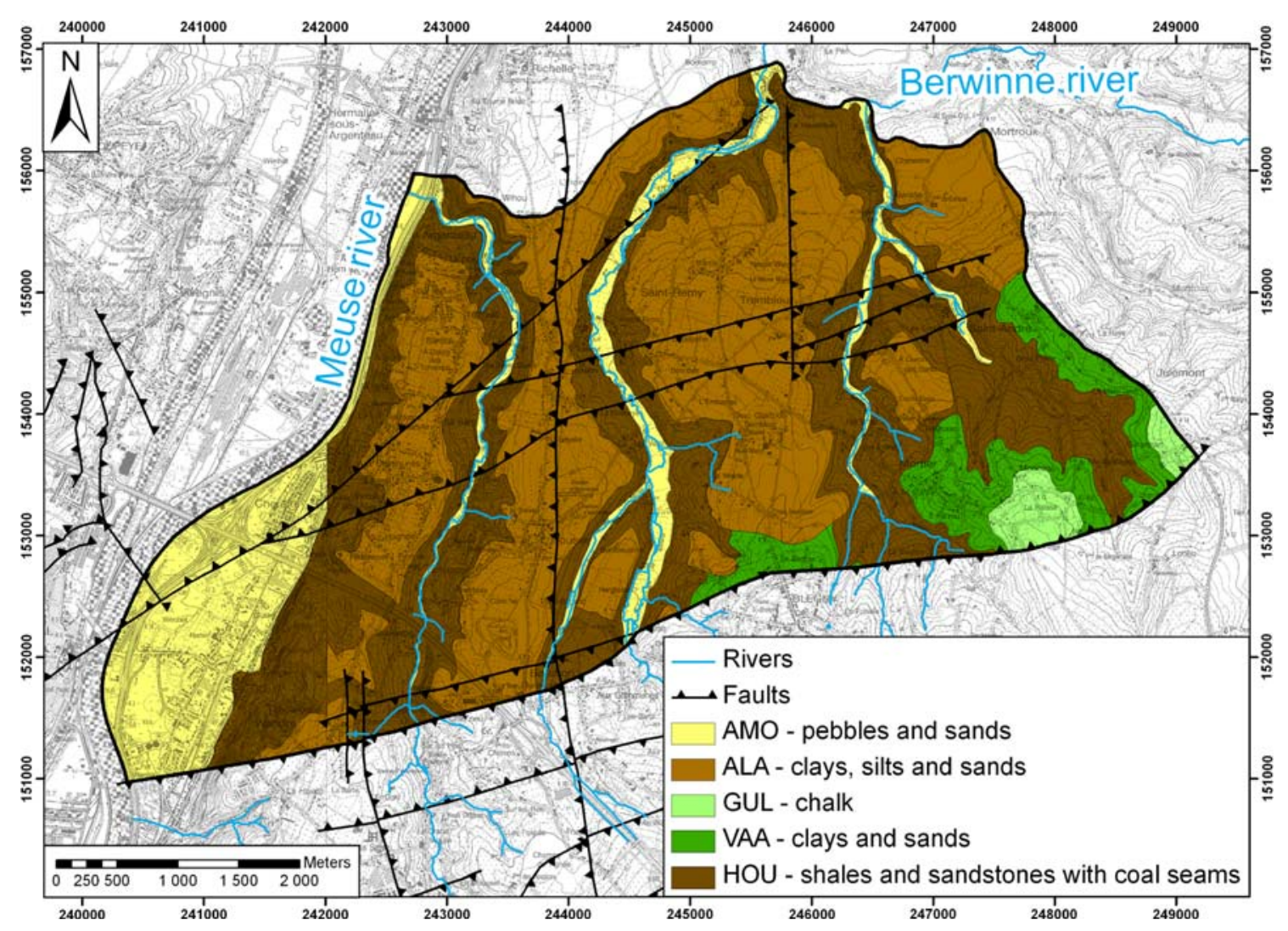

Fig. 9 Geological map of the case study zone [adapted from Barchy and Marion (2000)]

The ground water of the chalky aquifer flows mainly towards the northwest, following the dip of the Cretaceous formations, towards the Meuse River. However, this general trend is disturbed by the abandoned mined zones where significant drawdowns are sometimes observed.
Coal Exploitation and Ground Water Rebound

The coalfield of Liège was exploited from the Middle Ages but the industrial exploitation mainly took place during the nineteenth and twentieth centuries. The last collieries were 


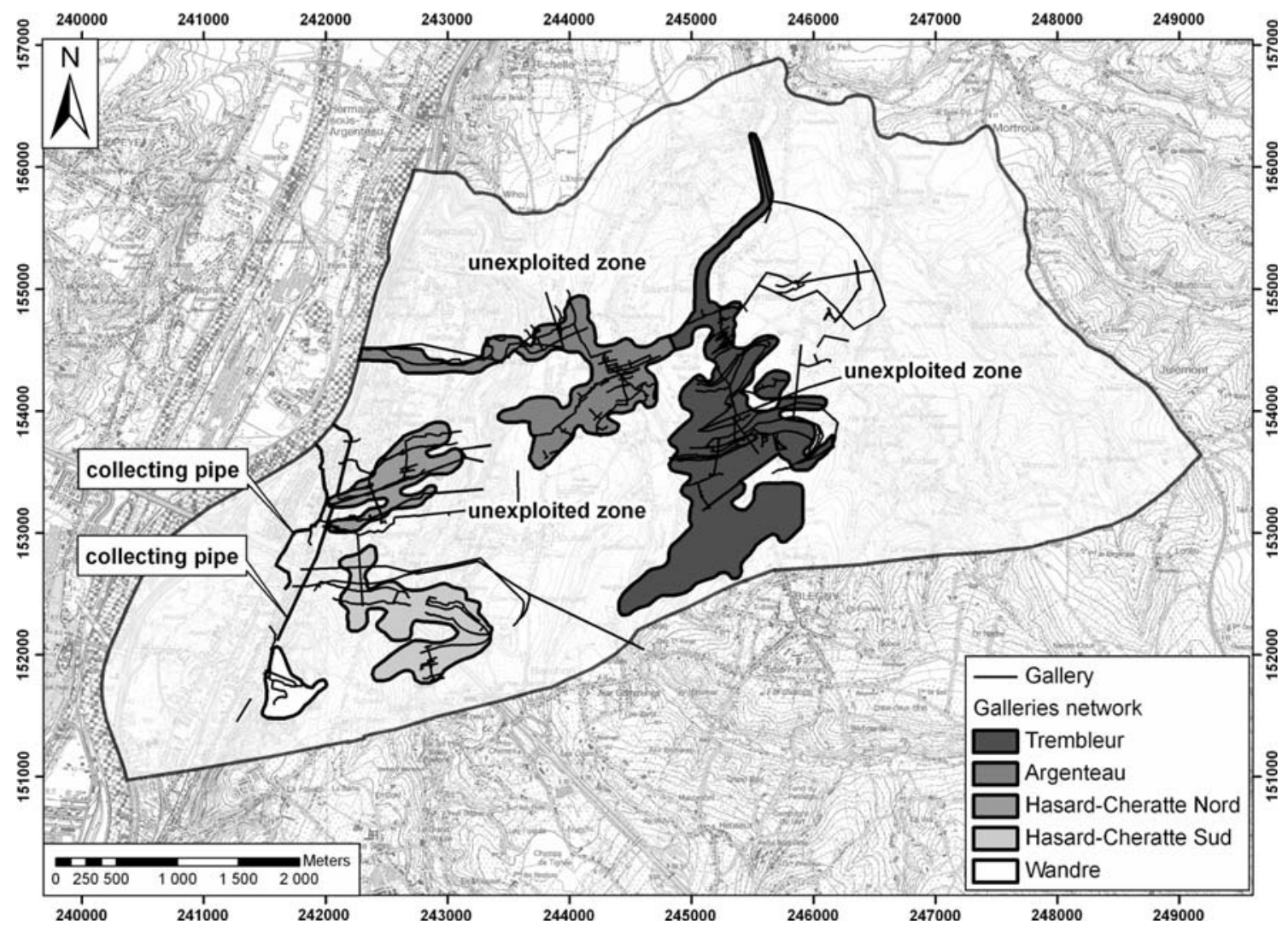

Fig. 10 Gallery networks of the Cheratte site

closed in the 1980s. According to available historical data, the Cheratte site was exploited until 1982 with five mined zones, Trembleur, Argenteau, Hasard-Cheratte Nord, Hasard-Cheratte Sud, and Wandre (Fig. 10), each made up of a network of galleries. These gallery networks are separate but some appear to be connected through faults or unknown mine workings, based on the strong correlation between the hydraulic heads and water discharge rates in some of the gallery networks (Fig. 11). For example, the water discharge in E8 (the drainage gallery of HasardCheratte Sud) correlates closely with the hydraulic heads in Pz4 (Argenteau) and Pz7 (Trembleur), while the hydraulic head in Pz8 (Hasard-Cheratte Sud) is almost stable. Consequently, the Argenteau and Hasard-Cheratte Sud galleries and the Trembleur and Hasard-Cheratte Sud galleries must be connected.

Pumping stopped at Cheratte in 1982 but the ground water rebound was not monitored until 1995 so the oldest hydraulic head measurements date from then. A piezometric network was installed in 2003 and measurements are now performed regularly. Although it is difficult to determine a general trend using available time series from 2003 , it seems that ground water has continued to rebound slightly. However, most of the ground water rebound has probably already taken place.

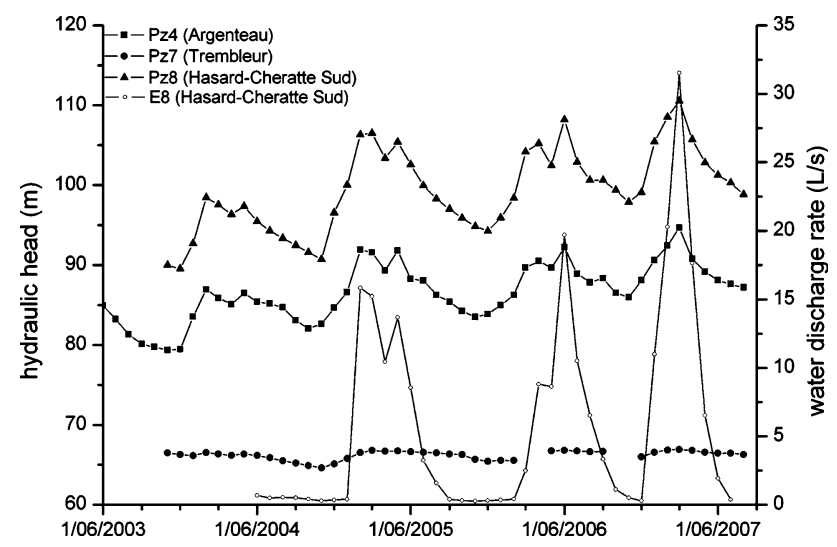

Fig. 11 Correlation between hydraulic heads and water discharge rates observed in different networks of galleries [adapted from Dingelstadt et al. (2007)]

\section{Steady-State Ground Water Flow Model}

The Cheratte site was modelled by subdividing the initial mesh (3 layers, 30,443 nodes, and 40,976 elements) into eight sub-domains: five representing the Trembleur, Argenteau, Hasard-Cheratte Nord, Hasard-Cheratte Sud and Wandre gallery networks, two representing collecting pipes of mine water, and one representing the adjacent and overlying unexploited rock masses (Fig. 12). 
Fig. 12 Initial mesh division into eight sub-domains

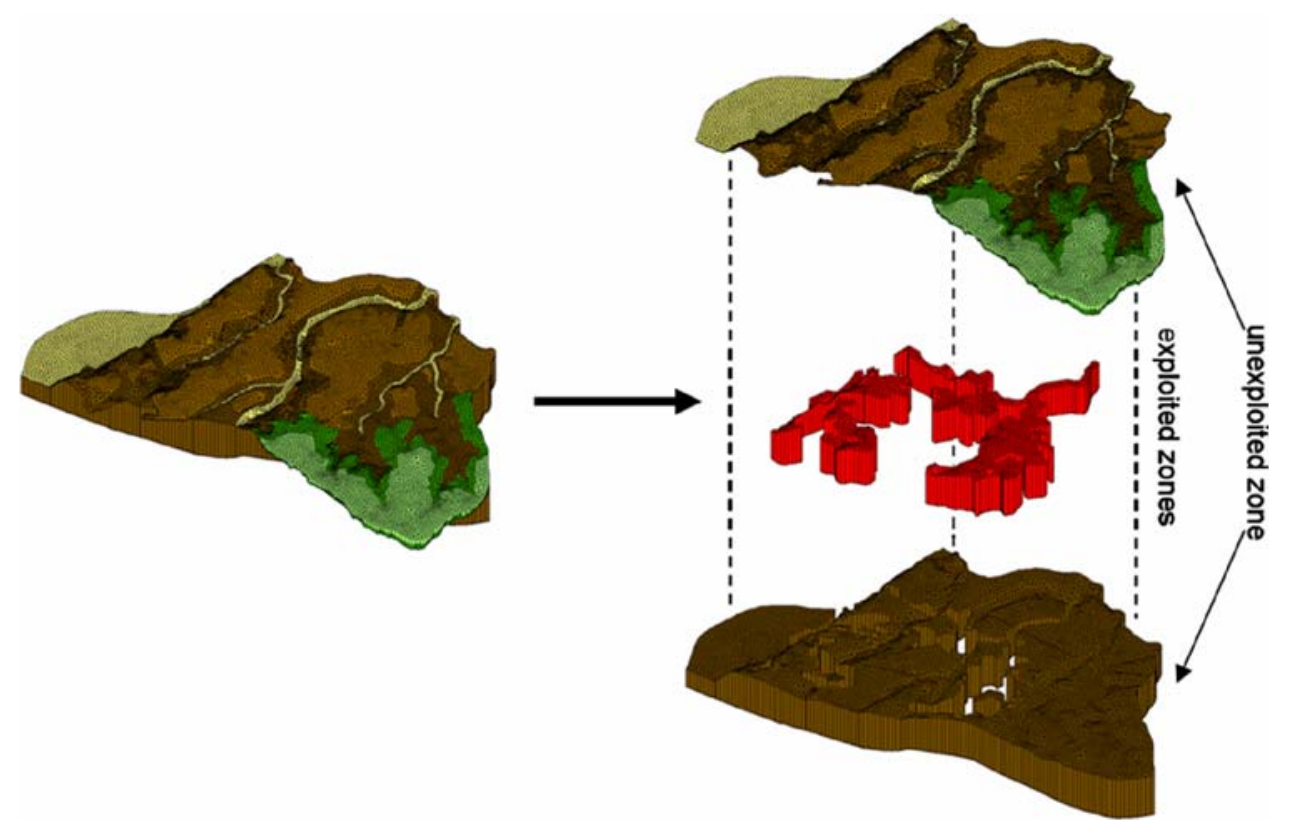

Internal boundary conditions between the sub-domains were defined as third-type dynamic boundary conditions to allow ground water fluxes exchanges between the five exploited zones and the unexploited rock mass. A third-type boundary condition was also prescribed at the western external boundary of the model corresponding to the Meuse River. Other external boundaries were considered as impervious because they correspond to a ground water divide or to faults filled with clay. Ten by-pass connections between exploited zones were also considered.

Transient simulations are required to use this model as a true predictive tool. However, as a first attempt, steadystate conditions were considered to test the ability of the model to reproduce the observed hydraulic head field and to obtain realistic initial conditions for future transient simulations. The model was calibrated comparing hydraulic heads observed at the beginning of January 2004 and simulated hydraulic heads provided by the model.

The calibrated parameters are the hydraulic conductivities of the geological formations and the exchange coefficients of Cauchy boundary conditions defined between sub-domains and by-pass connections between box models. The list of parameters used for this steadystate simulation is given in Table 4.

A scatter plot diagram of simulated versus observed ground water heads is presented in Fig. 13. The resulting distribution of ground water level throughout the modelled area is presented in Fig. 14. Analysing the simulated hydraulic heads, it appears that the HFEMC method reproduces the general ground water flow pattern oriented towards the northwest. Furthermore, the method reproduces the main water levels observed in the exploited zones as well as the drawdowns observed nearby.

\section{Conclusions}

The HFEMC method is a new, flexible method that has been developed and validated for the simulation of ground water flows in complex underground mined systems. The method couples a simplified approach (linear reservoir equation) for the exploited zones, most often poorly hydrogeologically characterised, with a classical approach (flow in porous media) for the adjacent and overlying unexploited zones. The method is able to take into account connections between exploited zones and can also simulate specific mine water phenomena, such as water inrushes.

A series of synthetic test cases and an application to an abandoned underground coal mine in the region of Liège illustrate the ability of the HFEMC method to model complex hydrogeological problems. Also, the mathematical and numerical concepts in the SUFT3D finite element code have been validated. The first results obtained for the Cheratte test site, in steady-state conditions, are promising since the method reproduces the mean water levels in the exploited zones as well as the general ground water flow patterns in the surrounding geological formations, as described by Ruthy and Dassargues (2008). Because of the high contrast in hydraulic conductivity between the mined and unmined zones, convergence problems could have 
Table 4 Application to the Cheratte coalfield (steady-state): parameters

\begin{tabular}{|c|c|}
\hline Parameter & Value \\
\hline$K_{\mathrm{HOU}}(\mathrm{m} / \mathrm{s})$ & $5 \times 10^{-6}$ \\
\hline$K_{\mathrm{VAA}}(\mathrm{m} / \mathrm{s})$ & $3 \times 10^{-6}$ \\
\hline$K_{\mathrm{GUL}}(\mathrm{m} / \mathrm{s})$ & $2 \times 10^{-5}$ \\
\hline$K_{\mathrm{ALA}}(\mathrm{m} / \mathrm{s})$ & $7 \times 10^{-5}$ \\
\hline$K_{\text {AMO }}(\mathrm{m} / \mathrm{s})$ & $7 \times 10^{-3}$ \\
\hline$\alpha_{\text {Trembleur-ext }}\left(\mathrm{s}^{-1}\right)$ & $7.75 \times 10^{-6}$ \\
\hline$\alpha_{\text {Argenteau-ext }}\left(\mathrm{s}^{-1}\right)$ & $6.00 \times 10^{-6}$ \\
\hline$\alpha_{\text {collecting pipe 1-ext }}\left(\mathrm{s}^{-1}\right)$ & $1.50 \times 10^{-5}$ \\
\hline$\alpha_{\text {collecting pipe 2-ext }}\left(\mathrm{s}^{-1}\right)$ & $3.00 \times 10^{-5}$ \\
\hline$\alpha_{\text {unexploited zone-ext }}\left(\mathrm{s}^{-1}\right)$ & $5.00 \times 10^{-5}$ \\
\hline$\alpha_{\mathrm{vert}}$, unexploited zone-Trembleur $\left(\mathrm{s}^{-1}\right)$ & $1 \times 10^{-4}$ \\
\hline$\alpha_{\mathrm{vert}, \text { unexploited zone-Argenteau }}\left(\mathrm{s}^{-1}\right)$ & $3 \times 10^{-5}$ \\
\hline$\alpha_{\mathrm{vert}}$ unexploited zone-Hasard-Cheratte Nord $\left(\mathrm{s}^{-1}\right)$ & $1 \times 10^{-5}$ \\
\hline$\alpha_{\mathrm{vert}}$, unexploited zone-Hasard-Cheratte Sud $\left(\mathrm{s}^{-1}\right)$ & $1 \times 10^{-5}$ \\
\hline$\alpha_{\text {vert, unexploited zone-Wandre }}\left(\mathrm{s}^{-1}\right)$ & $1 \times 10^{-5}$ \\
\hline$\alpha_{\text {hor, }}$ unexploited zone-exploited zones $\left(\mathrm{s}^{-1}\right)$ & $1 \times 10^{-7}$ \\
\hline$\alpha_{\text {Trembleur-Argenteau }}\left(\mathrm{m}^{2} / \mathrm{s}\right)$ & $3 \times 10^{-1}$ \\
\hline$\alpha_{\text {Trembleur-Hasard-Cheratte Nord }}\left(\mathrm{m}^{2} / \mathrm{s}\right)$ & $7 \times 10^{-3}$ \\
\hline$\alpha_{\text {Argenteau-Hasard-Cheratte Nord }}\left(\mathrm{m}^{2} / \mathrm{s}\right)$ & $5 \times 10^{-3}$ \\
\hline$\alpha_{\text {Hasard-Cheratte Nord-Hasard-Cheratte Sud }}\left(\mathrm{m}^{2} / \mathrm{s}\right)$ & $5 \times 10^{-3}$ \\
\hline$\alpha_{\text {Hasard-Cheratte Sud-Wandre }}\left(\mathrm{m}^{2} / \mathrm{s}\right)$ & $5 \times 10^{-3}$ \\
\hline$\alpha_{\text {Hasard-Cheratte Nord-collecting pipe } 2\left(\mathrm{~m}^{2} / \mathrm{s}\right)}$ & $1 \times 10^{-1}$ \\
\hline$\alpha_{\text {Hasard-Cheratte Sud-collecting pipe } 1}\left(\mathrm{~m}^{2} / \mathrm{s}\right)$ & $5 \times 10^{-1}$ \\
\hline$\alpha_{\text {Wandre-collecting pipe } 2}\left(\mathrm{~s}^{-1}\right)$ & $7 \times 10^{-2}$ \\
\hline$R_{\text {exploited zones }}(\mathrm{m} / \mathrm{s})$ & $1.49 \times 10^{-8}$ \\
\hline$R_{\text {unexploited zone }}(\mathrm{m} / \mathrm{s})$ & $1.31 \times 10^{-8}$ \\
\hline$H_{\text {ref-Trembleur }}(\mathrm{m})$ & 92 \\
\hline$H_{\text {ref-Argenteau }}(\mathrm{m})$ & 55 \\
\hline$H_{\text {ref-collecting pipes }}(\mathrm{m})$ & 55 \\
\hline$H_{\text {ref-unexploited zone }}(\mathrm{m})$ & 55 \\
\hline$\alpha_{\text {Trembleur-Hasard-Cheratte Sud }}\left(\mathrm{m}^{2} / \mathrm{s}\right)$ & $5 \times 10^{-3}$ \\
\hline$\alpha_{\text {Argenteau-Hasard-Cheratte Sud }}\left(\mathrm{m}^{2} / \mathrm{s}\right)$ & $5 \times 10^{-3}$ \\
\hline
\end{tabular}

$K$ hydraulic conductivity of the geological formations $\left(\mathrm{LT}^{-1}\right), \alpha_{i-j}$ exchange coefficient for Cauchy boundary conditions (external or internal) $\left(\mathrm{T}^{-1}\right)$ and by-pass connections $\left(\mathrm{L}^{2} \mathrm{~T}^{-1}\right), R$ recharge rate $\left(\mathrm{LT}^{-1}\right), H_{\text {ref }}$ drainage level (L). Recharge rate and drainage level have not been calibrated

been expected, but did not occur in any of the test cases performed using the HFEMC method in steady state conditions.

Future work will mainly consist of modelling transient conditions to use the model as a predictive tool for the evolution of ground water rebound. The convergence behaviour of the method on more complex transient problems will also be evaluated.

Consequently, the HFEMC method constitutes a useful management tool for mine water problems such as ground water rebound since it takes into account interaction

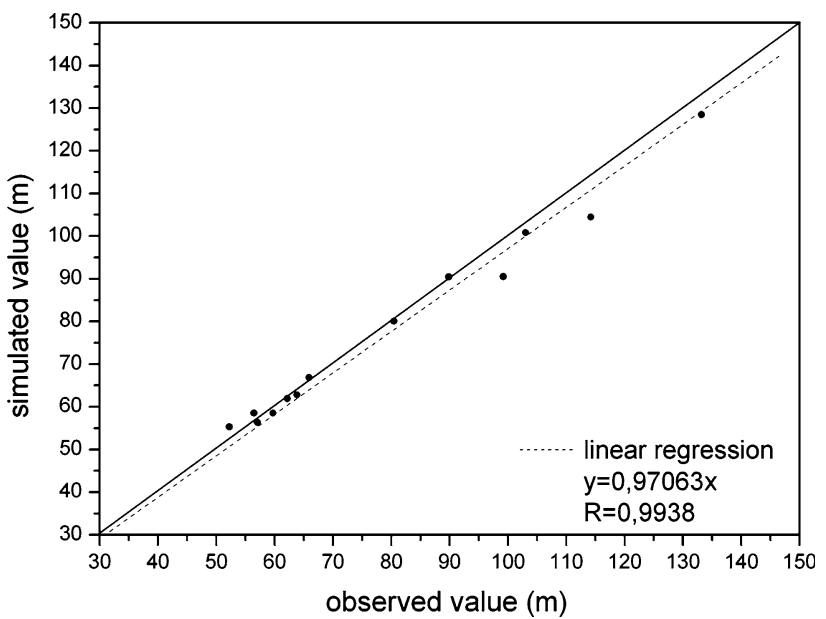

Fig. 13 Calibration of the steady-state model

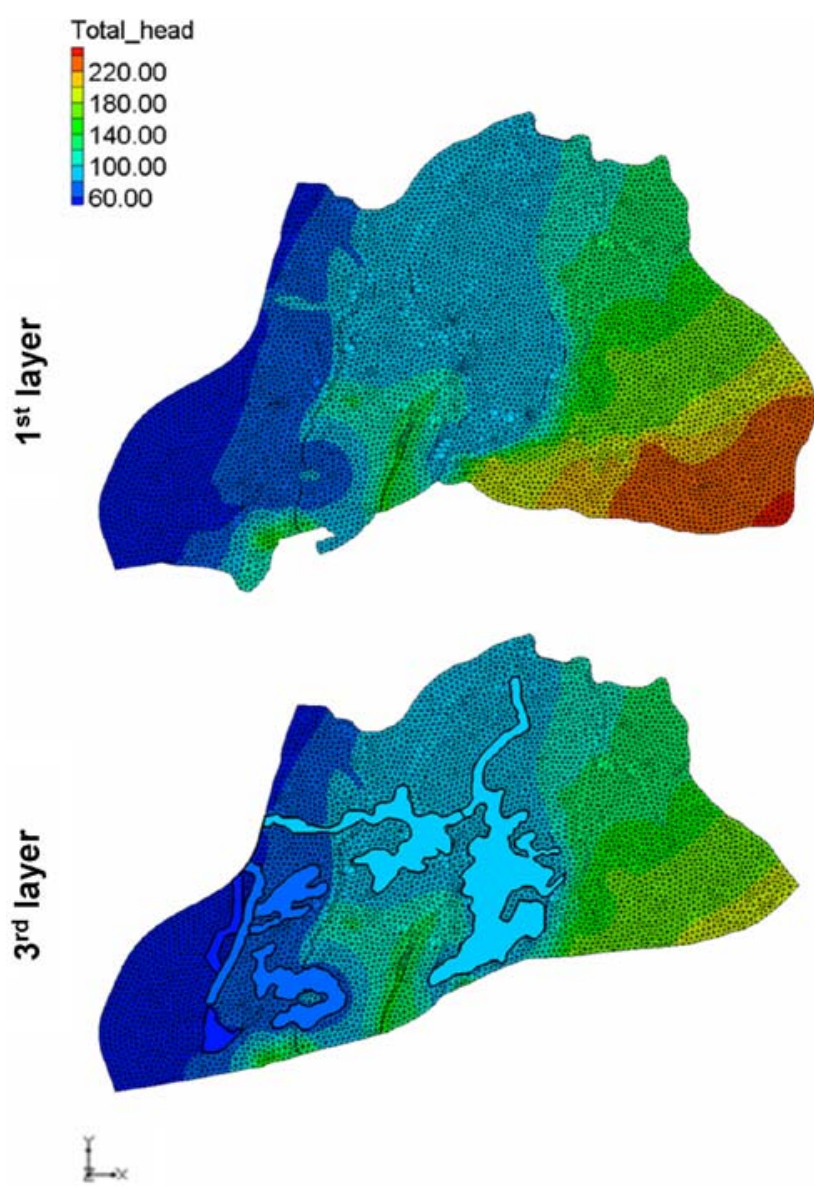

Fig. 14 Simulated hydraulic heads (in metres) for the steady-state model

between the exploitation zones as well as between exploited zones and the unexploited zone.

Acknowledgments The authors thank the Walloon Region, which has financially supported this project, together with the "Institut Scientifique de Service Public" (ISSeP) and the "Association 
Intercommunale pour le Démergement et l'Epuration" (AIDE). Conceptual and numerical developments of the HFEMC approach have also been performed in the framework of the Interuniversity Attraction Pole TIMOTHY (IAP Research Project P6/13), which is funded by the Belgian Federal Science Policy Office (BELSPO) and the European Integrated Project AquaTerra (GOCE 505428) with funding from the Community's Sixth Framework Programme.

\section{References}

Adams R, Younger PL (1997) Simulation of ground water rebound in abandoned mines using physically based modelling approach. In: Proceedings of the 6th international mine water association congress, Bled, pp 353-362

Barchy L, Marion J-M (2000) Carte géologique de Wallonie et notice explicative-Dalhem-Herve 42/3-4. Namur, Ministère de la Région Wallonne, Direction Générale des Ressources Naturelles et de l'Environnement

Boyaud C, Therrien R (2004) Numerical modelling of mine water rebound in Saizerais, northeastern France. In: Proceedings of the 15th international conference on computational method in water resources, Elsevier Science, Amsterdam, pp 979-989

Brouyère $S$ (2001) Etude et modélisation du piégeage de solutés en milieu variablement saturé. Faculté des Sciences Appliquées, University of Liège, Liège, $572 \mathrm{pp}$

Brouyère $S$, Carabin G, Dassargues A (2004) Climate change impacts on ground water resources: modelled deficits in a chalky aquifer, Geer basin, Belgium. Hydrogeol J 12:123-134
Carabin G, Dassargues A (1999) Modeling ground water with ocean and river interaction. Water Resour Res 35(8):2347-2538

Dingelstadt C, Drevet J-P, Veschkens M, Flamion B (2007). Etude des conséquences de l'après-mine en particulier sur la gestion des eaux souterraines et des risques-Mission 2006. Inst Scientifique de Service Public, Liege, $67 \mathrm{pp}$

Eckart M, Kories H, Rengers R, Unland W (2004) Application of a numerical model to facilitate mine water management in large coalfields in Germany. In: Proceedings of the mine water 2004process, policy and progress, Newcastle upon Tyne, pp 209-218

Rapantova N, Grmela A, Vojtek D, Halir J, Michalek B (2007) Ground water flow modelling applications in mining hydrogeology. Mine Water Environ 26:264-270

Ruthy I, Dassargues A (2008) Carte hydrogéologique de Wallonie et notice explicative-Dalhem-Herve 42/3-4. Namur, Ministère de la Région Wallonne, Direction Générale des Ressources Naturelles et de l'Environnement

Sherwood JM, Younger PL (1994) Modelling ground water rebound after coalfield closure: an example from County Durham. In: Proceedings of the 5th international mine water association congress, University of Nottingham, Nottingham, vol 2, pp 769777

Sherwood JM, Younger PL (1997) Modelling ground water rebound after coalfield closure. In: Proceedings of the 28th congress of the international association of hydrogeologists, Nottingham, UK, AA Balkema, Rotterdam, vol 1, pp 165-170

Younger PL, Banwart SA, Hedin SH (2002) Mine water: hydrology, pollution, remediation. Kluwer, London, p 464 